\title{
Literature and Ideology: The Penetration of Anglo-Irish Literature in Spain
}

\author{
Antonio Raúl de Toro \\ Universidad de La Coruña
}

\begin{abstract}
One important way of penetration of Irish literature and culture in Spain was through the northwestwern part of the country, Galicia in particular. Geographical, historical and ideological facts favoured a trend towards everything connected with Ireland. Therefore, Irish literature was studied, translated and became a model for some Galician critics and writers. One reason for this approach was entirely ideological: Ireland stood for a representative of the Celtic countries and Galicia was one of their members, or so they claimed. The implications of the Irish Literary Renaissance were carefully followed and, as a consequence, brought about cultural and literary manifestations inspired by the Irish movement.
\end{abstract}

The geographical position of the north west of the Iberian peninsular within a European context made it worthy of privileged maritime trading relations from time immemorial, fundamentally with countries to the north. To illustrate this point briefly we will refer to some revealing facts.

It seems to have been proved that there were sea links in prehistoric times between Galicia and the British Isles; at the end of the fourth century the coast of the province of Lugo was a home to a sizeable group of emigrants from Britanny who had fled the harassment of the Germanic tribes. To these we owe the place-name "Bretoña," which still exists today. The relationship with the Celtic nations of the Atlantic seaboard resulted in the entry of literature related with Britanny through Galicia into the rest of Spain.

Many years later, in 1388, John of Gaunt, Duke of Lancaster and Pretender to the crown of Castille, entered the port of La Coruña with his fleet and thus initiated his campaign to achieve his ambitions. La Coruña was the point of departure for Philip II and the fleet escorting him on his way to Southampton to marry Mary Tudor; later, in 1580, from this same port expeditions left to support the struggle of the Irish nationalists, an enterprise with a dramatic ending, in that the English soldiers, under the orders of Walter 
Raleigh and the poet Edmund Spenser, ruthlessly butchered all their prisoners, an event which caused a great impression in Europe. Again, in 1588, the Spanish Armada set sail from La Coruña, returning to this same destination after the disaster had been consummated. As a result, Drake and Norris carried out reprisals, attacking and besieging the city, although they were finally beaten off. Another significant event took place in 1589, when Pope Clement IV appointed an archbishop of Dublin, then in exile, with residence in Santiago de Compostela. La Coruña and Ferrol also had sizeable communities of Irish exiles, and in 1603 the Irish College was founded in Santiago. In 1689 the "Spanish packet," otherwise known as the "Corunna boat" made her maiden voyage, carrying mail between La Coruna and Falmouth in Cornwall, and making an average of twenty trips a year until 1815 . We might also point out, finally, the retreat of the British army by sea from Corunna and the death of Sir John Moore at the battle of Elviña during the Peninsular War.

These are just a few of the facts which show the strategic importance of the north west of the Iberian peninsular, turning it into a place of strategic interest with regard to sea routes towards the north of Europe, especially towards the British Isles. Even today legal protocol refers to lands bordering the sea as being bounded by "England, by way of the sea." It is thus hardly surprising that these historical events should have had repercussions in the world of culture in Galicia, there being a special interest in what could be called "the Irish problem."

It might be asked why Galician intellectuals and writers should have felt such sympathy towards the Irish in their long drawn out struggle against the English. One possible answer may be found in the social situation within Europe after the fall of Napoleonic power. Contemporary with the liberal revolution in France in 1830, the Romantic movement spread throughout Europe by means of political liberalism. In Spain the liberal restoration took place after the reign of Fernando VII, with all that that implied. Spain was a suitable breeding ground for the essences of this movement of liberalism, that is, among other things at a personal and political level, the emphasis on the self and the struggle against "tyranny" in the broadest sense of the word. It is within this context that the regionalist movements in Galicia and Catalunya in the 19th century must be understood, and one fundamental point of reference, at least in the case of Galicia, is represented by Ireland, considered a "sister nation," with its long history of catastrophes, but which, in spite of everything, never faltered in its fight for independence.

Regionalists like Alfredo Brañas, reformists like Concepción Arenal, poets such as Eduardo Pondal, historians such as Manuel Murguía, the husband of Rosalía de Castro, among others, turned to the Irish model when they spoke of the problems of Galicia. Nonetheless, interest in Ireland must be understood in a wider context; in other words, Ireland held an interest above all as a member of the Atlantic Celtic community, as was commonly accepted in the second half of the nineteenth century. The Celtic myth was introduced into Galicia by the historian José Verea y Aguiar in his book Historia de Galicia which was published in 1838 ; in this book he tries to demonstrate that everything Galician is Celtic, from its name to its language and customs, and he makes a comparative study of the cultural manifestations of Galicia with those of other Celtic countries, particularly Britanny and Ireland. From the date of this book on, the myth of Celtic Galicia 
is accepted by most Galician intellectuals, and is widespread, so much so that it becomes the main distinguishing factor of Galician identity within the Spanish state. This does not mean that everyone agreed, as, in fact, a break was produced between the "Celtistas," who felt a personal compromise with Galicia, defended its culture and were regionalists, and the "non-Celtistas," who were not. This situation remained more or less unchanged until the first third of the present century. Thus Ireland was ever-present and a compulsory point of reference, as is shown by the large number of political, social, cultural and literary articles published in magazines and newspapers.

It is necessary to stress, at this point, the role played by one magazine in particular. From 1920 to 1936 the magazine Nós was published, playing a major role in the development of Galician culture, as far as the popularization of European literature, the study of archeology, folklore, ethnography and literature were concerned. Nos was one of the most important expressions of the cultural awakening of modern Galicia and of the deepening of a nationalist conscience. This does not mean that this magazine was the first to take this step, as it was no more than one link in the chain of the process of dignifying the country culturally, a process which had already begun in the last third of the nineteenth century, following the pattern of other European regionalist movements. But the real importance of this magazine lies in its incorporation of the Galician language in all fields of knowledge, with the aim of putting it on an equal footing with Spanish itself, and to show that Gallego could be used for other purposes than literature and everyday language.

This interest in promoting the language as a differentiating factor for a community implied, besides, the defence of political rights so far denied it. In this way, the intellectuals involved in Nós looked for parallels in other Celtic peoples, and found their model, fundamentally, in Ireland. From this point of view, the so-called "Irish Literary Renaissance" had many parallels with what was happening in Galician literature under the name of "O Rexurdimento."

When the intellectuals who made up the so-called "Cova Céltica" began to probe into the origins and identity of Galicia, they realized that Galician culture lacked the mythical heroes found in the Greek and Roman tradition. It was found to be necessary to look for the cultural roots, and, as defenders of the Celtic identity of Galicia, they had no difficulty in finding legendary heroes in the Irish tradition. Such is the case of the legend of Breogán, who appears in the Lebor Gabala Erenn and who today forms an inseparable part of the Galician cultural background, being named in the Galician National Anthem. ${ }^{1}$

In the last quarter of the nineteenth century, Murguía made him known among his contemporaries at the discussions at the bookshop of Carré Aldao and in his publications, and the poet Eduardo Pondal, also known as "the Bard," influenced by the Ossian poems of Macpherson (1736-96), would make these heroes known popularly, together with those of his own creation, in Queixumes dos pinos. ${ }^{2}$

The magazine Nós, in this sense, channelled the studies about Galicia's ties with the European pan-Celtic movement, together with the political and cultural implications which it implied. Thus the political and cultural events in Ireland which had to do with its independence from Great Britain were followed with great interest by the intellectuals of the Nos generation. Ireland was of interest because it was a sister nation, and its struggle for independence was viewed with sympathy. This is clearly seen when issue number 8 
of the magazine, corresponding to December 1921, is devoted wholly to the memory of Terence MacSwiney, a writer and mayor of Cork, who had died after carrying out a politically motivated hunger strike.

Following in this line, one could mention, among others, articles such as "Irlanda e Galiza," a study about geographical parallelisms and historical events relating the two countries to each other, "O mes de santos nos pobos celtas," "O movemento pan-celtista," "Encol de poesía bárdica," and "Sant Yago na Bretaña." These articles try to explain that the culture of the Celtic peoples has much to do with Galicia, and so to attempt to come closer to them is no vain enterprise. They are signed by prominent figures in modern Galician literature, such as Vicente Risco, Ramón Otero Pedrayo, Ramón Cabanillas and Castelao.

We mentioned above that since the nineteenth century the myth of Celtism had served as a binding element in defence of the exaltation of everything Galician, but a consistent theoretical base was missing. This philosophical "scaffolding" was supplied, at least at the beginning, by Vicente Risco in various publications, to justify the reasons for an approach to the European nations on the Atlantic coast in all spheres.

Risco agreed with the thesis of Oswald Spengler concerning the decadence of the west, and judged that, given the Mediterranean character of western civilization, the hour had arrived for a renaissance of the Atlantic peoples, as, according to him, everything seemed to point to a shift in the centre of civilization from the Mediterranean to the Atlantic; he says that, once the great European power has been destroyed, the circumstances are favourable for a development of Celtism in the creation of an Atlantic civilization. He lists the seven Celtic nations of Europe: Scotland, the Isle of Man, Ireland, Wales, Cornwall, Britanny and Galicia, all of them symbolized by the lost civilization of Atlantis. In this respect he says the following:

Was Atlantis a historical continent? It maiters little. Atlantis, today covered by the briny waters of the ocean, is a symbol: it is the symbol of our Celtic civilization, darkened and subjected by an alien enemy civilization, that is the Mediterranean civilization, brought here by Roman imperialism, the prototype of all imperialisms. (Risco, Obra completa 74)

Parallel to this, the interest displayed by Nós in Irish letters is put into print, in the first place, in an analysis which Vicente Risco makes of the literary figure of W. B. Yeats (1865-1939), which has for its title "Letras irlandesas: W. B. Yeats." This introduction to the works of Yeats is followed on numerous later occasions by the translation of "Cathleen. ni Houlihan," preserving the same title, and that of "Our Lady of the Hills," which in its Gallego version is "Nosa Señora dos Outeiros." Despite the facts mentioned above, the same folk drama appears years later, in 1935 to be precise, issued by the publishers of Nos under the title of "Catuxa ni Houlihan," in Dous folk-dramas de W. B. Yeats, translated into Gallego by Plácido Ramón Castro and the brothers Vilar Ponte, forming part of the book.

In issue number 26, corresponding to the month of February 1926, Vicente Risco publishes the first of several articles about the panorama of Irish letters under the title of 
"A moderna literatura irlandesa," which will be the preface and introduction to lengthy passages of Ulysses, by James Joyce, published in issue number 32. The translation of these pages into Gallego by Otero Pedrayo deserves mention as being the first in Spain, before that of any other Peninsular tongue. It is also necessary to acknowledge the valour of Risco and Otero Pedrayo when they speak of Joyce, as the latter represented the opposite of the cause defended by Nos, that is, sympathy for Irish nationalism as a model to be followed in Galicia. As far as Nós was concerned, Joyce, together with other Irish writers, was a representative of Celtic values and genius, and if only for this reason deserved preferential attention in the magazine. All in all, the success of Joyce's work in Spain meant the triumph of the Atlantic movement, or, in other words, of "Celtism."

The translation of these fragments of Ulysses was made directly from English, as is reflected in the title "Postos en galego do texto inglés" (translated into Gallego from the English text), and its success owes as much to its exaltation of the Celtic spirit as to the special interest shown by the magazine in Galicia entering European literary circles without Madrid as literary "intermediary." The translation published in 1926 was carried out using as its original the 1925 edition of Ulysses prepared by Shakespeare and Company in Paris. The fragments chosen by Otero correspond to the chapter entitled "Ithaca" and to the end of "Cyclops," according to the order established in the translation.The origin of the former fragment is explained by Joyce himself in the following way:

I am writing "Ithaca" in the form of a mathematical catechism. All the events are resolved into their cosmic physical \& equivalents, e.g. Bloom jumping down the area, drawing water from the tap, the micturition in the garden.... (Qtd. Ellmann 516)

The fragment translated from "Cyclops," on the other hand, is written with the tone of a parody, and deals with the provocative issue of Irish nationalism.

Vicente Risco himself felt attracted by Joyce, and the outcome is a creative work entitled "Dédalus en Compostela." All the aforementioned demonstrates that Nós was in the forefront of European culture. Later on, Otero Pedrayo published an article entitled "Notes on the Landscape of Ancient Irish Epic," and finally, following the order of appearance in the magazine, the Gallego version of the book Lebor Gabala Erenn, also known as the Book of Invasions, is published in instalments.

In the introduction to the above mentioned article on Yeats, entitled "Irish letters: W. B. Yeats," Vicente Risco includes a brief poem by this poet as an illustration for his readers, not without warning his readers beforehand: "Even though I do not like translations, I am here offering you one." The title of the poem in Gallego is identical to that of its English original "To an Isle in the Water," and is remarkably faithful to the source text, maintaining in the Gallego version the type of assonance of rhyme in the even numbered lines, a typical feature of popular poetry and of ballads in English literature.

"Our Lady of the Hills," on the contrary, is a very short story which once again takes Irish folklore as its point of reference. Vicente Risco, its translator, in the introduction to Yeats' work which we have already mentioned, indicates that he would like to offer some tales by this writer in the magazine, and he cites several of these, among which is that which we are dealing with now, translated under the title "Nosa Señora dos Outeiros." 
Risco's version is impeccable, both from the aesthetic point of view and from that of being faithful to the original text, which is no mean feat when translations are under consideration.

The last translation we shall comment on is "Cathleen ni Houlihan." This is a short one-act play in which the subject of nationalism is once again dealt with. Yeats, in a letter written to Lady Gregory (1852-1932), explains to her the origins and significance of this folk-drama: Cathleen represents Ireland, the source and inspiration of countless legends and songs. The translator is, in this case, A. Vilar Ponte, who makes a relatively free translation, taking some liberties which, to say the least, are controversial. It is highly likely that the translator was more interested in the subject itself than in the aesthetic aspects of the play, though this is not to say that the general tone of his version is unacceptable.

We pointed out at the beginning of this article that the Galician literary movement known as the "Rexurdimento," with Rosalía de Castro, Curros Enríquez and Eduardo Pondal as its foremost figures, aimed to rescue the Galician language from its exclusively popular oral usage and raise it to a literary category. Naturally, this was only the first step, and little by little those interested in its recovery realized that the survival and the future of Galician culture meant it opening up to other European cultural circles, not necessarily coinciding with the indigenous regional ideal, a need that the Nós generation understood only too well in the first third of the present century.

In Ireland something of the same thing happens with the Irish Literary Renaissance at the end of the nineteenth century and the beginning of the twentieth, a movement combining a solid political nationalism with a great interest in the Gaelic literary tradition, and the founding of the Gaelic League in 1893 which may well be paralleled in Galicia by the "Irmandades da Fala" (Brothers of the Tongue). As is known, literary figures representative of this Irish renaissance are, among others, Yeats, Lady Gregory, Synge (and those in the Abbey Theatre group), George Russell (AE), Padraic Colum, Lord Dunsany and James Stephens.

The need for Galician culture to know and transpose to its language other foreign literary experiences finds another champion in Plácido Ramón Castro del Río. He is the personification of three basic qualities which serve as the bridge between English and Galician cultural expressions: a profound belief in his mission, a wide knowledge of English literature, and a great poetic sensitivity.

Correa Calderón, in A Nosa Terra expressed clearly the pressing need to establish ties with European literature, at the same time as he brought out three brief translations of Oscar Wilde, Omar Al-Khayyám and Rabindranath Tagore:

We must give to contemporary Galician literature a new and modern sense. We must also attempt to conquer that the Galician language should be flexible and ductile, in order to chisel in it new forms, new ideas ... Notwithstanding the opinions of the elders, that is, that everything Galician should remain in the nineteenth century, we believe should be given all the necessary words whether they are Portuguese, French or Italian... Literature and art must possess a modern aesthetics in order to be timeless ... We must 
make our contribution to giving the essential quality of modernness to this speech of gold and iron. (Calderón 2)

Precisely the latter was to be the task of a large group of writers and critics, among whom are prominent the above-mentioned Vicente Risco, Otero Pedrayo, Vilar Ponte and Plácido R. Castro, by their contributions to newspapers and periodicals such as A Nosa Terra, El Pueblo Gallego and above all Nós.

Nonetheless, as has already been pointed out, their search for inspiration was set in England and Ireland, arguing as they did for "Atlantism" (Risco, “A Atlántida”), as against the influence of Mediterranean culture. Plácido Ramón Castro, to our mind, is a key figure, often unfairly forgotten in the process of an approach to English and Irish literature, who put his principles into practice through articles, essays and translations. In fact, echoing an item of news in the British press which had as its principle protagonist the Prime Minister, Lloyd George, who defended the values of "Celtism," he states: "To pay attention to the northern Celtic lands must be part and parcel, the most important element, of what could be called our intellectual foreign policy" (Castro del Río, "O noso profeta” 11). In consequence, English literary expression, once taken as a model, will be reflected in its Galician counterpart, and one of its foremost promotors, as has been said, is Plácido Ramón Castro. Given his background in English, and together with his great love for Galicia, we would be hard put to find anyone else who could understand these cultures any better.

In accordance with his Atlantist ideology which we have mentioned previously, Plácido Castro published an article in 1927 entitled "El teatro gallego" in which he lays out the way he feels the newly-born Galician theatre should go. According to him, Galicia needed its own theatre through which regional drama production could be channeled. He believes that "the existence of an art theatre would stimulate the translation into Gallego of the world's dramatic masterpieces." As a model he quotes the case of Ireland:

We have at our fingertips a fountain of riches which, as well as containing these essential qualities is especially akin to the spirit of our race: Irish theatre. To inspire ourselves in it would not mean to copy it slavishly; it would mean studying the way in which a sister people of ours has managed to express its dreams, its woes, thus wakening our own latent sensitivity, somewhat drowsy due to so many centuries of intellectual domination by those who are alien to our character. (Castro del Río, “El teatro gallego" 1)

Naturally, the Irish authors he mentions are those in the Abbey Theatre group, that is, Yeats, Synge, Lady Gregory, Lord Dunsany, O'Casey, and, outside Ireland, Barrie, Maeterlinck and Strindberg. The reason why Galician theatre is inspired by that of its Irish counterpart is simple, he asserts: "In no other theatre as in the Irish do we have parading before us all of our own folklore: spells, treasures, witches, demons, fairy tale princesses, outlandish countries, the endless and tragic struggle of the Celtic soul between dream and reality. How vast is the chasm that divides all this from the latest stage success from Madrid." Castro, finally, wonders whether the theatre will come to form an essential part of Galician life as it does of Irish life. This question is shared by his contemporaries, and 
the outcome is that translations of the above-mentioned authors start to appear. Castro himself, together with the Vilar Ponte brothers, publishes in 1935 Dous dramas populares by W. B. Yeats, afterwards re-edited in 1977. This interest in Ireland and English literature had also been clearly reflected in another article "La Inglaterra céltica," in which he expounds the need for Galicia to pay attention to the north:

Galicia must look towards the misty lands of the north, to the lands of Ossian, Fingal and sorrowful Deirdre. And the intermediary between Galicia and these countries must be England, English culture, the only one in the world impregnated with the Celtic spirit. (Castro del Río, "El teatro gallego" 1)

Thus far, and to conclude, we have followed the traces of Irish influence in Galicia and its repercussions in the literary field. We have attempted to seek out the reasons for the interest in the Irish question shown by those intellectuals who had a cultural compromise towards Galicia, and how this sympathy results in the study and translation of Irish literature. The need to create mythical heroes for the recovery of Galician culture finds in Celtism and the theory of Atlantism an ideal ally which leads them to a unique point of reference: Ireland, the green isle of Erin.

\section{Notes}

1. Vicente Risco tells this legend in the following way: "The ancient chronicles of the isle of Erin ... preserve the old tradition of our king Breogán, of the tribe of Brigantium, son of Braha, grandson of Deyaha, direct descendant of Fenn, of the noble race of Gael, who raised in La Coruña the famous Brigantian lighthouse, from whose pinnacle his son Ith could make out on a clear winter's evening the distant land of Ireland. And, remembering a prophecy made by Kaiker the druid, he took an expedition made up of many ships, and when he arrived he was made welcome at first, but later was murdered there, and in vengeance, King Breogán and his other sons returned there and defeated the Fir-Bolgs and the Danands, and peopled Ireland, dividing it between Eber and Eremon, sons of Breogán" (Risco, "Irlanda e Galiza" 19).

2. Notwithstanding what is stated before, and unlike other Celtic peoples who have preserved their Celtic memory, Pondal feels obliged to introduce the names of imaginary heroes related with place-names of the area of Bergantiños.

\section{Works Cited}

Castro del Río, Plácido R. "El teatro gallego." El Pueblo Gallego, February 9, 1927: 1. . "O noso profeta." A Nosa Terra, July 25, 1928: 11.

Correa Calderón, Evaristo. “Páxinas extranxeiras.” A Nosa Terra, December 25, 1918: 2.

Ellmann, Richard. James Joyce. Oxford: Oxford UP, 1977.

Otero Pedrayo, Ramón. "Notes on the Landscape of Ancient Irish Epic." Nós 81 (1930): 176-78. trans. "Ulysses" [fragmentos] Nós 32 (1926): 3-11.

Risco, Vicente. “A Atlántida." A Fouce, July 52, 1932: 1. . "Dedalus in Compostela." Nós 67 (1929): 123-29. 
."Letras irlandesas: W. B. Yeats." Nós 3 (1920): 15-16.

. "Irlanda e Galiza." Nós 8 (1921): 18-20.

. "A Moderna Literatura Irlandesa." Nós 26, 27, 28 (1926): 5-9, 4-12, 2-5.

. Obra completa. Ed. Francisco J. Bobillo. Madrid: Akal, 1981.

, trans. "Cathleen ni Houlihan," by W. B. Yeats. Nós 8 (1921): 8.

trans. "Leabhar Gabhála: libro das conquistas d'Irlanda." Nós 86, 88, 92, 95 (1931): 23-26,

68-74, 139-44, 206-14.

trans. "Nosa Señora dos Outeiros," by W. B. Yeats. Nós 15 (1923): 12-13. 